\title{
Application of Plant Growth Regulators at Pre-harvest for Fruit Development of 'PÊRA' Oranges
}

\author{
Isolina Maria Leite de Almeida ${ }^{1}$, João Domingos Rodrigues ${ }^{2}$ and Elizabeth Orika Ono ${ }^{2 *}$ \\ ${ }^{1}$ Departamento de Produção Vegetal; Setor de Horticultura; Faculdade de Ciências Agronômicas; Campus de \\ Botucatu; Universidade Estadual Paulista - UNESP; 18618-000; Botucatu - SP - Brazil. ' Departamento de Botânica; \\ Instituto de Biociências; Universidade Estadual Paulista - UNESP; mingo@ibb.unesp.br; eoono@ibb.unesp.br; \\ C. P. 510; 18618-000; Botucatu - SP - Brazil
}

\begin{abstract}
The aim of the present work was to evaluate the effects of auxins and gibberellins when applied at pre-harvest to the fruit development, and to the ripening and natural fall of the fruit, in 'Pêra' oranges. Trees of Citrus sinensis Osbeck cv. Pêra, 5 years old, were utilized. The treatments applied were: $G A_{3}+2,4-D 12.5 m g L^{-1}$ of each; GA $3+$ 2,4-D 25mg L $L^{-1} ; G A_{3}+2,4-D$ 37.5mg L $L^{-1} ; G A_{3}+N A A 12.5 m g L^{-1} ; G A_{3}+N A A 25 m g L^{-1} ; G A_{3}+N A A 37.5 m g L^{-1}$; $N A A+2,4-D 12.5 m g L^{-1} ; N A A+2,4-D 25 m g L^{-1} ; N A A+2,4-D 37.5 m g L^{-1} ;$ and water (control). The treatments were applied 3 times, at intervals of 45 days. The variables evaluated were: rate of natural fall (\%), fruit length and diameter $(\mathrm{mm})$, and fresh fruit weight $(\mathrm{g})$. None of the treatments promoved alterations in the development of the fruits, but they did reduce the natural fall rate, when compared to control, up to $78.05 \%$, inhibiting the fruits' abscision as much as 3 months.
\end{abstract}

Key words: Auxins, gibberellins, fruit drop, development

\section{INTRODUCTION}

Citrus production is an activity of prime importance for the Brazilian economy. According to the Agrianual (2000) publication, the area occupied by citrus in the country is close to one million hectares, of which 850 thousand hectares are in the state of São Paulo. The export of juice produces a revenue of over 1.3 billion dollars annually, which places this product in third place among national exports. The cv. Pêra (Citrus sinensis Osbeck) is the most important citrus cultivar in Brazil, due mainly to the demand of the industry, and is the largest single type of citrus produced, with $53 \%$ of production in the state of São Paulo (Donadio et al., 1995).
The size of the fruit is important, not only because it is a component of productive yield, but also determines the acceptance by the consumer. The percentage of juice is an extremely important parameter for its industrial processing, being also related to size, which, in turn, although determined by the genetic characteristics of each cultivar, can be affected by cultural practices (Guardiola, 1992), such as application of plant growth regulators.

The juice yield of fruits depends not only on the extraction process but also on other factors, such as temperature, water supply, rootstock, cultivar, and age of tree. In Brazil, the Ministry of Agriculture sets the minimum juice yield at $40 \%$, for the varieties Bahia, Baianinha, Pêra, Natal, Valência, and Hamlin. This parameter is used not

\footnotetext{
* Author for correspondence
} 
only as an index of fruit quality, but also of maturity, as the juice yield increases with ripening. The natural fall of ripe citrus fruit is of great significance in commercial cultivars. In grapefruit, under conditions of Argentina, premature falling requires harvesting between July and September, but at this season the price received for the fruit does not meet the cost of production. The harvest season for 'Navel' oranges begins in April, and natural dropping begins in May and increases in the following months, the remaining fruit do not maintain the quality of the fruit harvested at the start of the season, as the peel loses its resistance (Ragone, 1992).

The application of plant growth regulators can re-enforce hormone balance in the peel, reducing or retarding this precocious fall and the losses at harvest (Primo et al., 1966). Monselise and Goren (1978) reported that the spraying of auxins prevented the dropping of fruit by maintaining the cells at the zone of abscision, preventing the synthesis of hydrolitic enzymes, such as cellulase, which decomposed the cell walls. Citing Riov (1974), the same authors reported that hormone balance acted on the polygalacturonase activity, which, together with cellulase, was responsible for the degradation of the two important components of cell walls, cellulose and pectin.

The use of 2,4-D as a growth regulator to promote size and to control fruit and leaf drop was reported by Hield et al. (1964) and Sarvoski and Stannard (1974) and has been recommended for California citrus crops (California Agricultural Extension Service, 1974).

According to El-Otmani (1992), the combined application of $\mathrm{GA}_{3}$ and 2,4-D reduces the precocious drop of fruit through the action of auxin and retards the softening and senescence of the peel, by the longer harvest time, and more economical storing in areas where stocking capacity is limited and cost is high.

Information on the absorption and excretion of 2,4-D in several species indicates that the compound is rapidly excreted unchanged, and that it is not stored in the tissues in mammals. According to FAO/WHO (1972), the acceptable daily intake 2,4-D for man allocated as 0 to $0.3 \mathrm{mg}$ $\mathrm{kg}^{-1}$ body weight. Washington Navel oranges were sprayed with $20 \mathrm{mg} \mathrm{kg}^{-1}$ 2,4-D as practised for growth regulation and preharvest fruit drop. Orange samples were taken before, 1 day after and 7 days after spraying. Residues of 2,4-D averaged $<0.1 \mathrm{mg} \mathrm{kg}^{-1}$ before, $0.1 \mathrm{mg} \mathrm{kg}^{-1} 1$ day after, and <
$0.1 \mathrm{mg} \mathrm{kg}^{-1} 7$ days after treatment (Erickson and Hield, 1962).

This work was aimed at evaluating the effects of auxins and gibberellins, when applied pre-harvest for the development of the fruit and for rate of drop to determine the possibility of retarding harvest of cv. Pêra, for citrus fruit.

\section{MATERIALS AND METHODS}

The experiment was conducted under field conditions on Fazenda São João, a farm belonging to Citrovita Agro-Industrial Ltd. in the County of Itapetininga, SP. The plants utilized were of Citrus sinensis Osbeck, cv. Pêra, grafted onto Rangpur lime rootstock (Citrus limonia Osbeck) of 5 years of age. During the course of the experiment, the normal cultural practices with regard to nutrition, weed control, pests, and diseases were utilized.

The foliar treatments employed were: 1- $\mathrm{GA}_{3}$ 12.5mg L $\mathrm{m}^{-1}+2,4-\mathrm{D} 12.5 \mathrm{mg} \mathrm{L}^{-1} ; 2-\mathrm{GA}_{3} 25 \mathrm{mg} \mathrm{L}^{-1}+$ 2,4-D $25 \mathrm{mg} \mathrm{L}^{-1} ; 3-\mathrm{GA}_{3} 37.5 \mathrm{mg} \mathrm{L}^{-1}+2,4-\mathrm{D}$ $37.5 \mathrm{mg} \mathrm{L}^{-1} ; 4-\mathrm{GA}_{3} 12.5 \mathrm{mg} \mathrm{L}^{-1}+\mathrm{NAA} 12.5 \mathrm{mg} \mathrm{L}^{-}$ ${ }^{1}$; 5- $\mathrm{GA}_{3} 25 \mathrm{mg} \mathrm{L}^{-1}+\mathrm{NAA} 25 \mathrm{mg} \mathrm{L}^{-1} ; 6-\mathrm{GA}_{3}$ $37.5 \mathrm{mg} \mathrm{L}^{-1}+$ NAA $37.5 \mathrm{mg} \mathrm{L}^{-1} ; 7$ - NAA $12.5 \mathrm{mg} \mathrm{L}^{-}$ ${ }^{1}+2$,4-D $12.5 \mathrm{mg} \mathrm{L}^{-1} ; 8$ - NAA $25 \mathrm{mg} \mathrm{L}^{-1}+2,4-\mathrm{D}$ $25 \mathrm{mg} \mathrm{L}^{-1}$; 9- NAA $37.5 \mathrm{mg} \mathrm{L}^{-1}+2,4-\mathrm{D} 37.5 \mathrm{mg} \mathrm{L}^{-1}$; 10- control (water). To the treatments an surfactant, Extravon $(0.3 \%)$ containing $250 \mathrm{~g} \mathrm{~L}^{-1}$ of alkyl-phenol-polyglycolether was added. The plants were sprayed with approximately 4 liters of solution per plant. During the experimental period three applications were made, the first on May, 24 at the start of the change in fruit color, the second 45 days later, and the third 45 days after that. Avoiding 2,4-D application on windy to minimize damage in borders cultures.

The experiment was made totally at random with six plants in line for each section, the middle four for evaluation of natural fall, and the two end ones for fruit development. The groups in the same row were separated by a plant, and the rows were separated by a non-treated row of plants to avoid any drift effect. Ten treatments with six repetitions each were made, totaling 60 plots.

The variables evaluated were as follows: length of fruit $(\mathrm{mm})$, diameter of fruit $(\mathrm{mm})$, weight of fresh fruit $(\mathrm{g})$, and rate of natural fall of fruit (\%). These variables were evaluated in seven harvests, the first on May, 24 just before the treatment began, and the others at intervals of about 45 days, the last being on January, 29. 
The index of natural fall was obtained by weekly counting of fallen fruit beneath the tree shade, those with no sign of insect action, by lot of four plants, adding, in each count, to the number previously counted, expressed in percentage of total fruit extant in each lot (El-Otmani et al., 1990). However, as these values observed up to the third harvest were close to zero, this variable was analyzed statistically after the fourth collection. The diameter and length of the fruit was obtained with the aid of a gauge, and the mass of the fruit was obtained by weighing immediately after harvest. At each harvest, five fruits were selected at random from each of the two end plants for 10 fruit per unit sample.

For data analysis, the multi-varied linear model (Morrison, 1967) was employed, simultaneously testing the differences for each of the variables studied. For the analysis, the program PERFIL (Profile) of Rosa (1994) was used, testing for 5 hypothesis:

$\mathrm{H}_{01}=$ the profiles of the seven groups are parallel, 5 hypothesis being tested.

$\mathrm{H}_{02}=$ accepting $\mathrm{H}_{01}$, there are no differences among the 10 treatments, considering a global profile.

$\mathrm{H}_{03}=$ accepting $\mathrm{H}_{01}$, there are no differences among the 4 conditions for the lot of 10 treatments.

$\mathrm{H}_{04}=$ there are no differences between the 4 conditions in each treatment.

$\mathrm{H}_{05}=$ analysis of variance to verify treatment effect within each condition.

As the number of repetitions (six) in the experiment was lower than the number of conditions for evaluation (seven), it became necessary, for statistical analysis, to separate the number of conditions into two periods: $1^{\text {st }}$ period, referring to harvests I,II,III, and IV, and the $2^{\text {nd }}$ period referring to harvests V,VI, and VII. In all the statistic analysis, the level of probability adopted was of $5 \%$.

\section{RESULTS AND DISCUSSION}

\section{Length of fruit}

The first hypothesis tested for profile analysis $\left(\mathrm{H}_{01}\right)$ of length of fruit with reference to the parallel character of the 10 treatments studied was not rejected for this variable, denoting absence of interaction between treatment and harvest for evaluation, following the rate of maturation of citrus fruit. Once this hypothesis of parallelism was satisfied, the verification of $\mathrm{H}_{02}$ and $\mathrm{H}_{03}$ was made for comparison of treatments and of harvests (Table 1). In this case, significant effects of treatment were not observed (effects of plant growth regulators) however, significant effects of harvests were observed. From Table 1 and Fig. 1, it can be seen that the average gains in length in the 10 treatments studied present parallel and coincident profiles $(p>0.05)$, showing no significant differences among them.

However, among the periods of harvest, significant differences could be observed from the first to the fourth period, demonstrating that fruit length increased up until the fourth harvest period, right after which length stabilized.

The absence of differenced in length among the treatments agreed with the findings of Coggins Jr. et al. (1960), who also not found statistical differences for this parameter with the application of gibberellic acid on 'Lisboa' lemon. This also agreed with data observed by Barros (1992) for 'Ponkan' tangerines, where the application of $\mathrm{GA}_{3}$ alone or in conjunction with 2,4-D made no significant differences between treatments, the same also occurring with 'Hamlin' oranges with different doses of $\mathrm{GA}_{3}, 2,4-\mathrm{D}$, and NAA (Almeida, 1996).

According to Garcia-Luiz et al. (1992), applications of $\mathrm{GA}_{3}$ at $10 \mathrm{mg} \mathrm{L}^{-1}$ on 'Clementina' tangerines reduced peel thickness and also retarded change of color of the fruit, with no observable effect on growth or composition and percentage of juice of the fruit.

\section{Diameter of Fruit}

The first hypothesis tested in the profile analysis $\left(\mathrm{H}_{01}\right)$ of fruit diameter, referring to the parallelism of the profiles of the ten treatments was not rejected for this variable, denoting similar behavior in treatments during the experiment. Once this hypothesis was satisfied, verification of hypothesis $\mathrm{H}_{02}$ and $\mathrm{H}_{03}$ was made for comparison of treatments and dates of harvest (Table 2). In this case, significant effects were observed with relation to treatments in the second period, but were observed for dates of harvest in both periods. From Table 2 and Fig. 2, it could be deduced that the average gains in diameter of the fruit in the 10 treatments studied presented parallel and coincident profiles $(\mathrm{p}>0.05)$, showing no significant differences among them in the first 
period. In the second period, significant effects for treatments were observed, being the control different of the $\mathrm{GA}_{3} 25 \mathrm{mg} \mathrm{L}^{-1}+2,4-\mathrm{D} 25 \mathrm{mg} \mathrm{L}^{-1}$; $\mathrm{GA}_{3} 37.5 \mathrm{mg} \mathrm{L}^{-1}+2,4-\mathrm{D} 37.5 \mathrm{mg} \mathrm{L}^{-1}$ and $\mathrm{GA}_{3}$ $37.5 \mathrm{mg} \mathrm{L}^{-1}+$ NAA $37.5 \mathrm{mg} \mathrm{L}^{-1}$.

The results observed here agreed with those described by Barros (1992), where the application of $\mathrm{GA}_{3}$ alone or with 2,4-D provoked significant increase of fruit diameter compared to the control.
They also agreed with the findings of Coggins Jr. and Henning (1988), who described that the application of $\mathrm{GA}_{3}$ at $40 \mathrm{mg} \mathrm{L}^{-1}$ on 'Valencia' oranges caused increase of fruit size as measured for length and diameter. Aranguren et al. (1988), also reported increase of length and diameter of 'Valencia' oranges with pre-harvest application of 2,4-D in concentrations of 20 and $25 \mathrm{mg} \mathrm{L}^{-1}$.

Table 1 - Results of multivaried analysis of profiles for length of fruit (mm) of 'Pêra' oranges, submitted to treatment with plant growth regulators, on dates of harvest.

\begin{tabular}{l|c|c|c}
\hline \multicolumn{1}{c|}{ Statistical hypothesis } & Periods & $\begin{array}{c}\text { Statistical analysis } \\
\text { results }\end{array}$ & Conclusion \\
\hline Parallelism if profiles $\left(\mathrm{H}_{01}\right)$ & $1^{\text {st }}$ & $\theta=0.272(\mathrm{p}>0.05)$ & There are similarity among profiles \\
& $2^{\text {nd }}$ & $\theta=0.258(\mathrm{p}>0.05)$ & \\
Coincidence among profiles $\left(\mathrm{H}_{02}\right)$ & $1^{\text {st }}$ & $\mathrm{F}=1.020(\mathrm{p}>0.05)$ & $1=2=3=4=5=6=7=8=9=10$ \\
& $2^{\text {nd }}$ & $\mathrm{F}=2.400(\mathrm{p}>0.05)$ & $1=2=3=4=5=6=7=8=9=10$ \\
Time effect $\left(\mathrm{H}_{03}\right)$ & $1^{\text {st }}$ & $\mathrm{F}=190.0(\mathrm{p}<0.05)$ & $\mathrm{I}<\mathrm{II}<$ III $<$ IV \\
& $2^{\text {nd }}$ & $\mathrm{F}=2.00(\mathrm{p}>0.05)$ & $\mathrm{V}=\mathrm{VI}=\mathrm{VII}$ \\
\hline
\end{tabular}

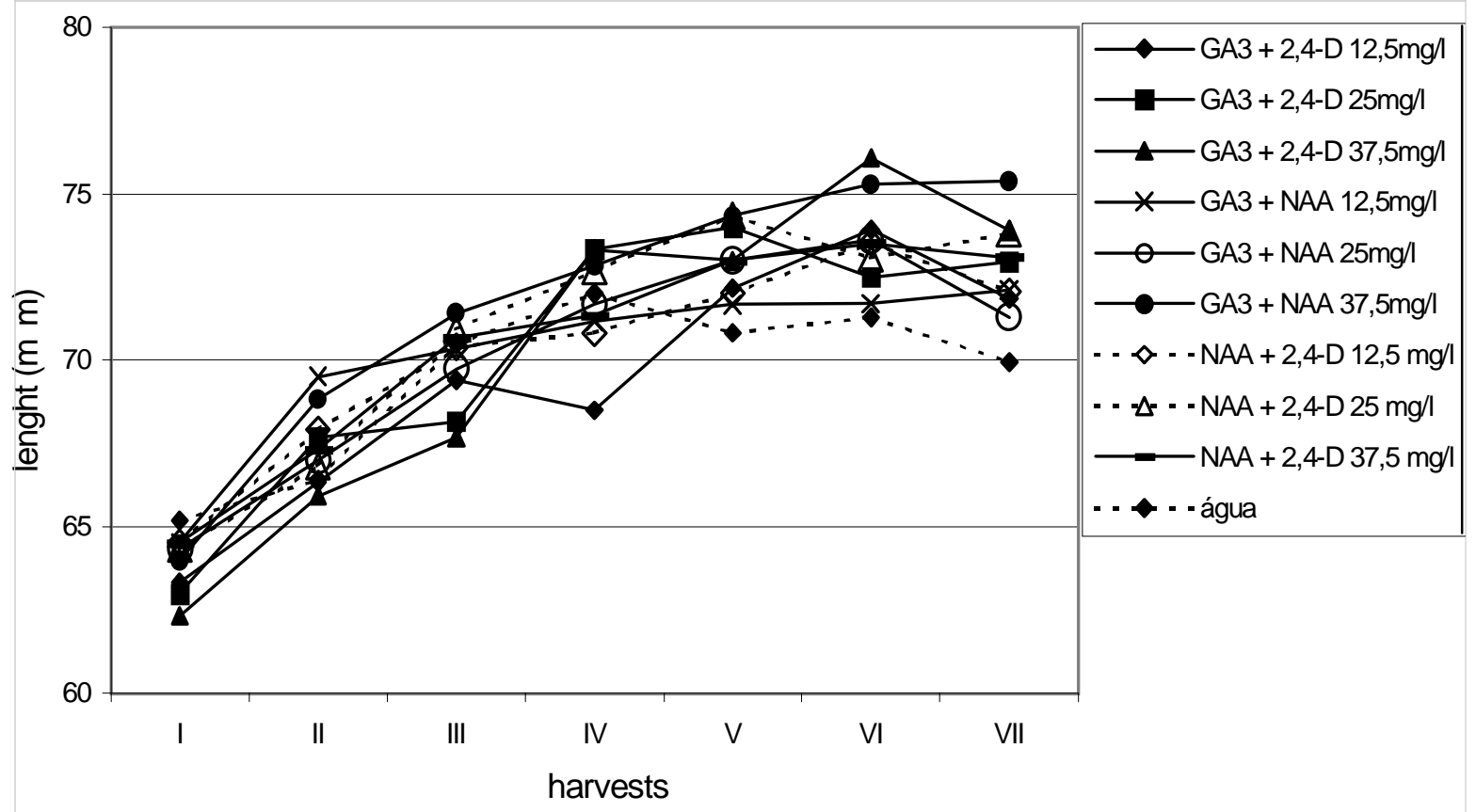

Figure 1 - Averages of lenght of fruit (mm) of 'Pera' oranges, submitted to treatment of plant growth regulators, on the seven dates of harvest. 
However, the results found here disagreed with those of Coelho et al. (1978), where applications of $\mathrm{GA}_{3}+2,4-\mathrm{D}$ on 'Cravo' tangerines did not alter fruit diameter. They also disagreed with those obtained by Al-Mughrabi et al. (1989) on 'Balaby' oranges sprayed with 2,4-D at 100 and $200 \mathrm{mg} \mathrm{L}^{-1}$. Zaragoza et al. (1977), working with 'Washington Navel' oranges found no statistical differences of diameter or length of the fruit treated with 2,4-D at 8 and $16 \mathrm{mg} \mathrm{L}^{-1}$, alone or with $\mathrm{GA}_{3}$ at $10 \mathrm{mg} \mathrm{L}^{-1}$. This was also reported by Almeida (1996), when working with 'Hamlin' oranges also found no statistical differences between those treated with plant growth regulators and the controls. The growth of the fruit of 'Pêra' oranges occurs from the flowering until maturity, due to the increasing accumulation of dry matter during growth, attaining full growth coincident with the end of the dropping of small fruit, and then remaining stable for several months. Shortly before maturity, there occurs a great increase of fresh mass in the fruit, due to the accumulation of water (Guardiola, 1992).

\section{Fresh Mass of Fruit}

The first hypothesis tested in profile analysis $\left(\mathrm{H}_{01}\right)$, of fresh fruit mass, with reference to parallelism of profiles in the 10 treatments, was not rejected, denoting similar behavior for the treatments during the duration of the experiment, or absence of interaction between treatment and harvests of evaluation. With this hypothesis satisfied, hypothesis $\mathrm{H}_{02}$ and $\mathrm{H}_{03}$ were verified for comparison of treatments and harvests for evaluation (Table 3). In this case, significant effects for treatments in second period were observed and significant effects were observed for harvests (Fig. 3).

These results agreed with those found by Barros (1992) on 'Ponkan' tangerines using treatments with $\mathrm{GA}_{3}$ at 20 and $200 \mathrm{mg} \mathrm{L}^{-1}$, and $\mathrm{GA}_{3}$ at $20 \mathrm{mg}$ $\mathrm{L}^{-1}+2,4-\mathrm{D}$ at $20 \mathrm{mg} \mathrm{L}^{-1}$, which led to significant increase of fruit mass compared with control, and the second treatment presented the highest average increase. Application of 2,4-D also led to increase of fruit mass in 'Washington Navel' oranges, with concentration of $40 \mathrm{mg} \mathrm{L}^{-1}$ (Keleg and Minessy, 1965) and in 'Valencia' oranges, at 15, 20, and $25 \mathrm{mg} \mathrm{L}^{-1}$ (Aranguren et al., 1988).

However, results here disagreed with those described by Coelho et al. (1978), where the authors don't observed effects on mass of 'Cravo' tangerines with the use of $\mathrm{GA}_{3}$ at 10,20 , and $30 \mathrm{mg}$
$\mathrm{L}^{-1}$, even if association with 2,4-D. These results also disagreed with those of Zaragoza et al. (1977), who applied $\mathrm{GA}_{3}$ with 2,4-D on 'Washington Navel' oranges, finding no differences in mass. No differences were found in 'Valencia' oranges using $\mathrm{GA}_{3}$ at 10,20 , and $40 \mathrm{mg}$ $\mathrm{L}^{-1}$ (Coggins Jr. and Henning, 1988).

The results obtained in this work, also showed that treatments with $\mathrm{GA}_{3}+2,4-\mathrm{D}$ at 25.0 and $37.5 \mathrm{mg}$ $\mathrm{L}^{-1}$ and $\mathrm{GA}_{3}+\mathrm{NAA}$ at $37.5 \mathrm{mg} \mathrm{L}^{-1}$ presented significant difference with control to increase the fresh fruit mass. Increase of mass was observed up to the fourth harvest, showing statistical difference between harvests I, II, III, and IV, and difference between VI and VII. Starting with harvest V, a pronounced decrease in fruit mass was observed. This decrease could have been caused by water loss due to an unusually low rainfall in that month. The steadily increasing fruit mass from the first through the fourth harvest supported the observation realized when examining the fruit for length and diameter. That the timing of application of plant growth regulators was not the ideal one for promoting growth of the fruit as these probably had already reached maximum size, showing an increase only in mass due to accumulation of water.

The increase of fresh fruit mass up to the fourth harvest agreed with the results observed by Barros (1992) that mass increase of 'Ponkan' tangerines continued until the fourth harvest, approximately 120 days after application, falling off on the fifth and last harvest, also due to low rainfall; they also agreed with Almeida (1996), where increase of mass was observed in 'Hamlin' oranges treated with different plant growth regulators up to the sixth harvest, which added up to approximately the same number of days as in the present work.

\section{Rate of Natural Fall of Fruit}

Verifying the analysis referring to the rate of natural dropping of fruit, as seen in Table 4, it could be seen in Table 4, it could be seen that the hypothesis of parallelism also was not rejected, suggesting that there was no interaction between treatment and time of measurement. The results in Fig. 4 showed that the profiles of the 10 treatments were similar $(p>0.05)$ with no statistically significant difference observed among them, but following the hypothesis $\mathrm{H}_{02}$ and $\mathrm{H}_{03}$, a statistical difference was observed; treatments 1,2 , and 3 coincided, but all three differed from the control, treatment 10 . These treatments were those using 
$\mathrm{GA}_{3}+2,4-\mathrm{D}$ applied together, leading to the lowest rate of fall, agreeing with the results reported by Keleg and Minessy (1965) with 'Washington Navel' oranges, where spraying with 2,4-D at 10,20 , and $40 \mathrm{mg} \mathrm{L}^{-1}$ reduced the rate of fall, compared to control. Fig. 4, showed that the rates of fall increase with time, for all the treatments.

According to Patil et al. (1989), the effects of plant growth regulators in reducing the rate of premature fall of 'Kinow' mandarins were significant compared to control, when 2,4-D was applied at 10,20 , or $30 \mathrm{mg} \mathrm{L}^{-1}$, and the application of GA or NAA, did not show the same effect when compared to control. The same authors found that spraying with NAA at $10 \mathrm{mg} \mathrm{L}^{-1}$ with urea at $2 \%$ also significantly reduced the rate of fall, but less efficiently when compared with the treatments that contained 2,4-D.

Table 2 - Results of multivaried analysis of profiles for diameters of fruit (mm) of 'Pêra' oranges, submitted to treatments with plant growth regulators, on dates of harvest.

\begin{tabular}{l|r|r|r}
\hline \multicolumn{1}{c}{ Statistical hypothesis } & Periods & $\begin{array}{c}\text { Statistical analysis } \\
\text { results }\end{array}$ & Conclusion \\
\hline Parallelism if profiles $\left(\mathrm{H}_{01}\right)$ & $1^{\text {st }}$ & $\theta=0.289(\mathrm{p}>0.05)$ & There are similarity among profiles \\
& $2^{\text {nd }}$ & $\theta=0.158(\mathrm{p}>0.05)$ & \\
Coincidence among profiles $\left(\mathrm{H}_{02}\right)$ & $1^{\text {st }}$ & $\mathrm{F}=0.820(\mathrm{p}>0.05)$ & $1=2=3=4=5=6=7=8=9=10$ \\
& $2^{\text {nd }}$ & $\mathrm{F}=5.560(\mathrm{p}<0.05)$ & $2 ; 3 ; 6 \neq 10$ \\
Time effect $\left(\mathrm{H}_{03}\right)$ & $1^{\text {st }}$ & $\mathrm{F}=132.42(\mathrm{p}<0.05)$ & $\mathrm{I}<\mathrm{II}<\mathrm{III}=\mathrm{IV}$ \\
& $2^{\text {nd }}$ & $\mathrm{F}=5.37(\mathrm{p}<0.05)$ & $\mathrm{V}=\mathrm{VI}=\mathrm{VII}$ (V $\neq$ VII $)$ \\
\hline
\end{tabular}

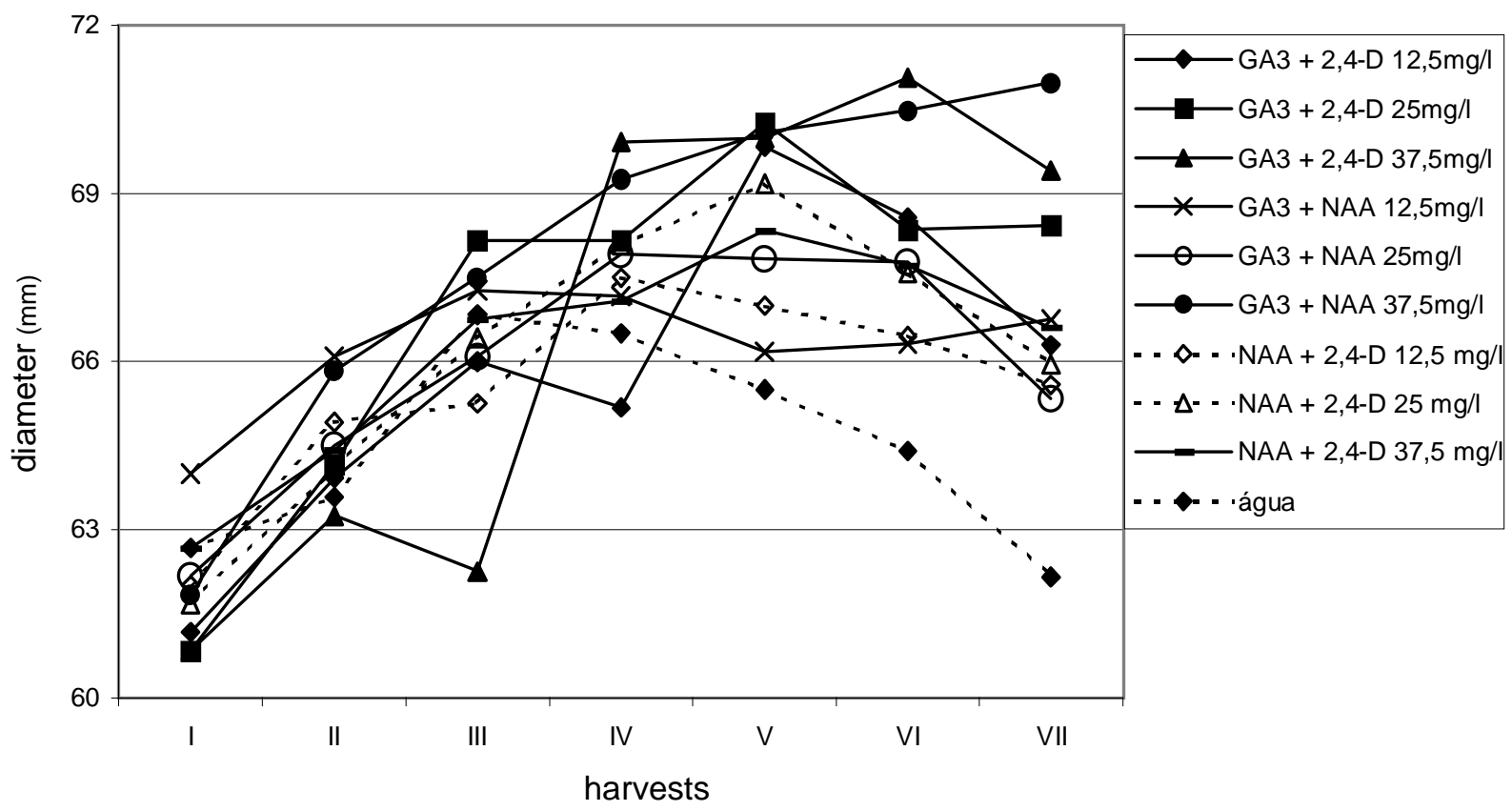

Figure 2 - Average of diameter of fruit (mm) of 'Pera' oranges, submitted to treatments with plant growth regulators, on the seven dates of harvest. 
Table 3 - Results of multivaried analysis of profiles for fresh fruit mass ( $g$ ) of 'Pêra' oranges, submitted to treatment with plant growth regulators, on the various dates of harvest.

\begin{tabular}{l|c|c|c}
\hline \multicolumn{1}{c}{ Statistical hypothesis } & Periods & $\begin{array}{c}\text { Statistical analysis } \\
\text { results }\end{array}$ & Conclusion \\
\hline Parallelism if profiles $\left(\mathrm{H}_{01}\right)$ & $1^{\text {st }}$ & $\theta=0.303(\mathrm{p}>0.05)$ & There are similarity among profiles \\
& $2^{\text {nd }}$ & $\theta=0.201(\mathrm{p}>0.05)$ & \\
Coincidence among profiles $\left(\mathrm{H}_{02}\right)$ & $1^{\text {st }}$ & $\mathrm{F}=0.560(\mathrm{p}>0.05)$ & $1=2=3=4=5=6=7=8=9=10$ \\
& $2^{\text {nd }}$ & $\mathrm{F}=4.690(\mathrm{p}<0.05)$ & $2 ; 3 ; 6 \neq 10$ \\
Time effect $\left(\mathrm{H}_{03}\right)$ & $1^{\text {st }}$ & $\mathrm{F}=270.49(\mathrm{p}<0.05)$ & $\mathrm{I}<\mathrm{II}<\mathrm{III}<\mathrm{IV}$ \\
& $2^{\text {nd }}$ & $\mathrm{F}=5.26(\mathrm{p}<0.05)$ & $\mathrm{V}=\mathrm{VI} \neq \mathrm{VII}$ \\
\hline
\end{tabular}

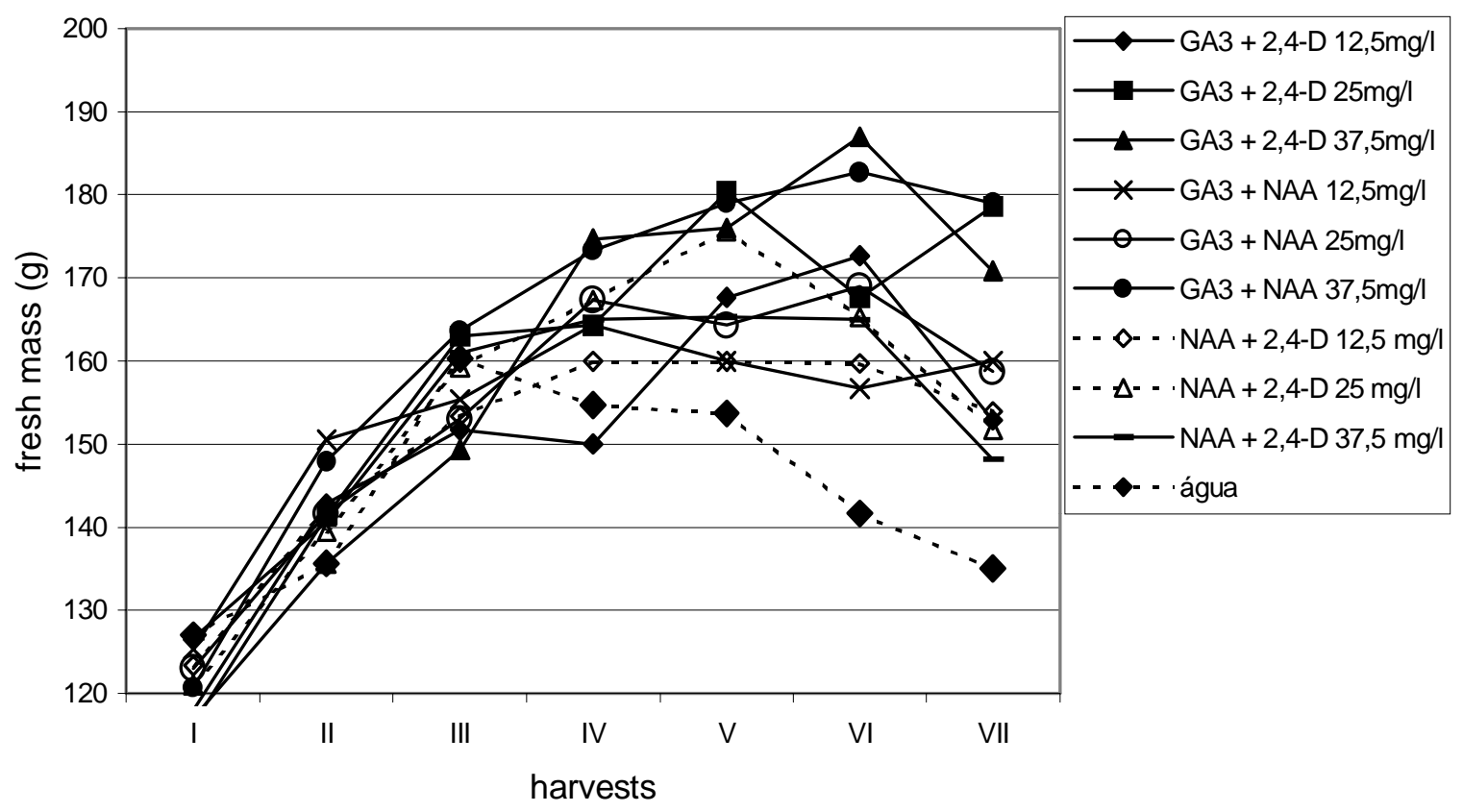

Figure 3 - Averages fresh fruit mass ( $\mathrm{g}$ ) of 'Pera' oranges, submitted to treatments with plant growth regulators, on the seven dates of harvest.

Fig. 4 showed that all the treatments containing plant growth regulators were effective in reducing fall of fruit, but at different levels. The treatment with $\mathrm{GA}_{3}$ at $12.5 \mathrm{mg} \mathrm{L}^{-1}+2,4-\mathrm{D}$ at $12.5 \mathrm{mg} \mathrm{L}^{-1}$ presented reduction of natural fall of $67.65 \%$; the treatment with $\mathrm{GA}_{3}$ at $37.5 \mathrm{mg} \mathrm{L} \mathrm{L}^{-1}+2,4-\mathrm{D}$ at $37.5 \mathrm{mg} \mathrm{L}^{-1}$ showed $64.65 \%$ reduction; with $\mathrm{GA}_{3}$ at $12.5 \mathrm{mg} \mathrm{L}^{-1}+\mathrm{NAA}$ at $12.5 \mathrm{mg} \mathrm{L}^{-1}$ the reduction was of $56.63 \%$; with $\mathrm{GA}_{3}$ at $25 \mathrm{mg} \mathrm{L}^{-1}+\mathrm{NAA}$ at $25 \mathrm{mg} \mathrm{L}^{-1}$ the reduction found was of $46.40 \%$; $\mathrm{GA}_{3}$ at $37.5 \mathrm{mg} \mathrm{L}^{-1}+\mathrm{NAA}$ at $37.5 \mathrm{mg} \mathrm{L}^{-1}$, reduction was $55.69 \%$; with NAA at $12.5 \mathrm{mg} \mathrm{L}^{-1}+2,4-\mathrm{D}$ at $12.5 \mathrm{mg} \mathrm{L}^{-1}$, the reduction was $32.67 \%$; with NAA at $25 \mathrm{mg} \mathrm{L}^{-1}+2,4-\mathrm{D}$ at $25 \mathrm{mg} \mathrm{L}^{-1}$, it was $31.83 \%$;

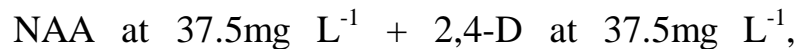
$25.36 \%$; and finally a natural fall of $78.05 \%$ was obtained with a treatment with $\mathrm{GA}_{3}$ at $25 \mathrm{mg} \mathrm{L}^{-1}+$ 2,4-D at $25 \mathrm{mg} \mathrm{L}^{-1}$. Although there were no very large differences in natural fall among the treatments with plant growth regulators, on 'Pêra' oranges, the largest reductions were obtained with the combination of $\mathrm{GA}_{3}$ and 2,4-D.

These results were in agreement with Almeida (1996) working with 'Hamlin' oranges, where the most effective treatment was with $25 \mathrm{mg} \mathrm{L}^{-1}$ of each. These results also agreed with El-Zeftawi (1980), where all the treatments with $\mathrm{GA}_{3}$ and 2,4$\mathrm{D}$, isolated or in combination, significantly 
reduced the fall of grapefruit, when compared to control, and also was considered the best treatment for maintaining the quality of peel, allowing prolongation of the harvest without alteration of quality of the fruit.

Stewart and Hield (1950) reported that the fall of mature fruit was characterized mainly by alterations in the cellular walls in the zone abscision, localized at the peduncle, and that the main action of plant growth regulators in the fall of ripe fruit was that of reducing the weakening of the cellular wall material in this region, reducing the fall of fruit. NAA presented the same positive effect on the layer of abscision. This dependence of abscision relative to the endogenous content of auxins has been proven by exogenous applications of 2,4-D or NAA, as the transportation of auxins by the plant lasts for a long time without ethylene appearing to affect it (Agustí and Almela, 1991). These facts could explain the low rate of fall also found in the treatments with $\mathrm{GA}_{3}$ at $12.5 \mathrm{mg} \mathrm{L}^{-1}+$ $\mathrm{NAA}$ at $12.5 \mathrm{mg} \mathrm{L}^{-1} ; \mathrm{GA}_{3} 25 \mathrm{mg} \mathrm{L}^{-1}+\mathrm{NAA}$ at $25 \mathrm{mg} \mathrm{L}^{-1}$; and $\mathrm{GA}_{3}$ at $37.5 \mathrm{mg} \mathrm{L}^{-1}+\mathrm{NAA} 37.5 \mathrm{mg}$ $\mathrm{L}^{-1}$, all of which contained the combination of $\mathrm{GA}_{3}$ and NAA. Apparently, the interaction of these two regulators were as effective as the treatments containing $\mathrm{GA}_{3}$ and 2,4-D.

Table 4 - Results of multivaried analysis of profiles for rate of natural fall (\%) of 'Pêra' oranges, submitted to treatment with plant growth regulators, on the various dates of harvest.

\begin{tabular}{lc|r|r}
\hline \multicolumn{1}{c|}{ Statistical hypothesis } & Periods & $\begin{array}{c}\text { Statistical analysis } \\
\text { results }\end{array}$ & Conclusion \\
\hline Parallelism if profiles $\left(\mathrm{H}_{01}\right)$ & $2^{\text {nd }}$ & $\theta=0.535(\mathrm{p}>0.05)$ & There are similarity among profiles \\
Coincidence among profiles $\left(\mathrm{H}_{02}\right)$ & $2^{\text {nd }}$ & $\mathrm{F}=5.23(\mathrm{p}<0.05)$ & $1 ; 2 ; 3 \neq 10$ \\
Time effect $\left(\mathrm{H}_{03}\right)$ & $2^{\text {nd }}$ & $\mathrm{F}=203.07(\mathrm{p}<0.05)$ & IV $<\mathrm{V}<$ VI $<$ VII \\
\hline
\end{tabular}

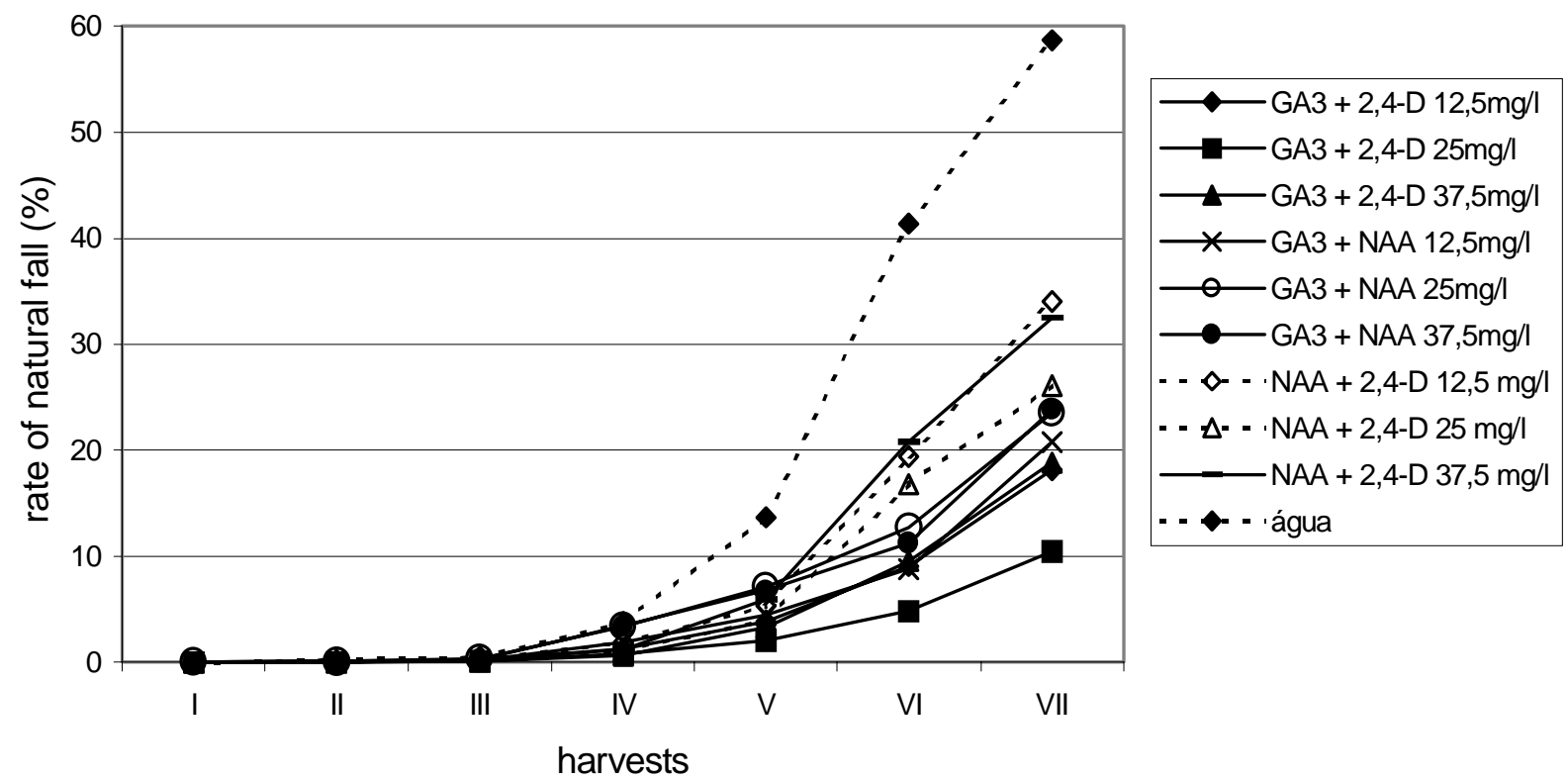

Figure 4 - Averages of rate of natural fall (\%) of 'Pera' oranges, submitted to treatments with plant growth regulators, on the seven dates of harvest. 
An interesting fact to be emphasized was that the treatments that contained only the auxins were those that presented the highest rate of fall, other than the control. This could be due to phytotoxicity, or the high concentration of auxins which could promove abscision.

From the results of evaluation of length, diameter, fresh fruit mass, and rate of fall, it could be seen that the treatment of 'Pêra' oranges at the time of change of color, with gibberellin and auxins did not affect the development of the fruit, but effectively retarded the process of abscision of the fruit.

Under the conditions of the study, and based on the results obtained, it could be concluded that the utilization of plant growth regulators had no influence on the development of the fruit, such as length, diameter and fresh fruit mass of 'Pêra' oranges; however, the treatments did inhibit the natural fall of the fruit, permiting the prolongation of the harvest season, particularly high-lighting the treatments with $\mathrm{GA}_{3}$ at $25 \mathrm{mg} \mathrm{L}^{-1}+2,4-\mathrm{D}$ at $25 \mathrm{mg} \mathrm{L}^{-1}$.

\section{RESUMO}

O trabalho objetivou avaliar os efeitos de auxinas e giberelinas, combinados e aplicados em précolheita no desenvolvimento e na taxa de queda natural de frutos de laranjeira 'Pêra'. Foram utilizadas árvores de laranjeira (Citrus sinensis Osbeck) cultivar Pêra com 5 anos de idade. Os tratamentos foram: $\mathrm{GA}_{3}+2,4-\mathrm{D} 12,5 \mathrm{mg} \mathrm{L}^{-1} \mathrm{de}$ cada; $\mathrm{GA}_{3}+2,4-\mathrm{D} 25 \mathrm{mg} \mathrm{L} \mathrm{L}^{-1} ; \mathrm{GA}_{3}+2,4-\mathrm{D}$ $37,5 \mathrm{mg} \mathrm{L}^{-1} ; \mathrm{GA}_{3}+\mathrm{NAA} 12,5 \mathrm{mg} \mathrm{L}^{-1} ; \mathrm{GA}_{3}+\mathrm{NAA}$ $25 \mathrm{mg} \mathrm{L}^{-1} ; \mathrm{GA}_{3}+\mathrm{NAA} 37,5 \mathrm{mg} \mathrm{L}^{-1} ; \mathrm{NAA}+2,4-\mathrm{D}$ $12,5 \mathrm{mg} \mathrm{L}^{-1}$; NAA + 2,4-D $25 \mathrm{mg} \mathrm{L}^{-1} ; \mathrm{NAA}+2,4-\mathrm{D}$ $37,5 \mathrm{mg} \mathrm{L}^{-1}$ e testemunha (água). Durante todo o período experimental foram realizadas três aplicações a intervalos de 45 dias. As variáveis avaliadas foram: Taxa de queda natural dos frutos (\%), comprimento (mm), diâmetro (mm) e massa fresca dos frutos $(\mathrm{g})$. Nenhum dos tratamentos proporcionaram alterações no desenvolvimento final dos frutos, mas reduziram a taxa de queda natural em comparação com a testemunha em até $78,05 \%$, inibindo a abscisão dos frutos em até três meses.

\section{REFERENCES}

Agrianual (2000), Anuário da Agricultura Brasileira. São Paulo : FNP. pp. 281-310.

Agustí, M. and Almela, V. (1991), Aplicación de fitorreguladores en citricultura. Barcelona : AEDOS. pp. 261.

Almeida, I. M. L. (1996), Efeitos da aplicação de fitorreguladores, na maturação e na taxa de queda dos frutos da laranjeira 'Hamlin' (Citrus sinensis Osbeck.). Dissertação (Mestrado), Universidade Estadual Paulista, Botucatu, Brazil.

Al-Mughrabi, M. A.; Bacha, M. A. and Abdelrahman, A. O. (1989), Influence of preharvest application of ethrel and 2,4-D on fruit quality of 'Baladi' oranges. J. King Saud Univ. Agric. Sci., 1, 95-102.

Aranguren, M.; Alfaro, D. and Castro, Y. O. (1988), Efecto de aplicaciones precosecha de 2,4-D sobre el desarrollo del fruto y el control de la caídas por rajaduras em naranja 'Valência'. Ciênc. Tec. Agric. Cítricos Otros Frutales, 11, 113-120.

Barros, S. A. (1992), Efeitos da aplicação pré-colheita de fitorreguladores, no desenvolvimento final $e$ maturação do fruto da tangerineira 'Ponkan' (Citrus reticulata Blanco). Dissertação (Mestrado), Universidade Estadual Paulista, Botucatu, Brazil.

California Agricultural Experiment Station Extension Service (1974), Treatment guide for California citrus crops. pp. 50-51.

Coelho, Y. S. et al. (1978), Ácido giberélico e 2,4-D em citros. II. Efeitos na maturação da tangerina 'Cravo' (Citrus reticulata Blanco). Rev. Bras. Fruticult., 1, 31-44.

Coggins Jr., C. W. and Henning, G. L. (1988), A comprehensive California field study of the influence of preharvest applications of gibberellic acid on the rind quality of Valencia oranges. Isr. J. Bot., 37, 145-154.

Coggins Jr., C. W.; Hield, H. Z. and Garber, M. J. (1960), The influence of potassium gibberellins on Valencia orange trees and fruit. J. Am. Soc. Hortic. Sci., 76, 193-198.

Donadio, L. C.; Figueiredo, J. O. and Pio, R. M. (1995), Variedades cítricas brasileiras. Jaboticabal : FUNEP. pp. 228.

El-Otmani, M. (1992), Usos principais de reguladores de crescimento na produção de citros. Paper presented at Seminário Internacional de Citros, Bebedouro, Brazil.

El-Otmani, M.; Barek, A. A. and Coggins Jr., C. W. (1990), $\mathrm{GA}_{3}$ and 2,4-D prolong on tree storage of citrus in Morocco. Sci. Hortic., 44, 241-249.

El-Zeftawi, B. W. (1980), Regulating pre-harvest fruit drop and duration of the harvest season of grapefruit with 2,4-D and GA. J. Hortic. Sci., 3, 211-217.

Erickson, L. C. and Hield, H. Z. (1962), Determination of 2,4-dichloro-phenoxyacetic acid in citrus fruit. J. Agr. Food Chem., 10, 204-207. 
FAO/WHO (1972), 1971 Evaluations of some pesticides residues in food. $\mathrm{n} .1$.

Garcia-Luíz, A.; Herrero-Villen, A. and Guardiola, J. L. (1992), Effects of applications of gibberellic acid on late growth, maturation and pigmentation of the Clementine mandarin. Sci. Hortic., 49, 71-82.

Guardiola, J. L. (1992), Frutificação e crescimento. Paper presented at 2. Seminário Internacional de Citros - Fisiologia, Bebedouro, Brazil.

Hield, H. Z.; Burns, R. M. and Coggens, C. W. (1964), Pre-harvest use of 2,4-D on citrus. University Circular, 528, 3-10.

Keleg, F. M. and Minessy, F. A. (1965), Effect of 2,4-D on juice drop, preharvest drop, fruit quality and alternate bearing in 'Baladi'mandarin and 'Washington Navel'orange. J. Agric. Res., 12, 47-67.

Monselise, S. P. and Goren, R. (1978), The role of internal factors and exogenous control in flowering, peel growth, and abscission in citrus. Hortscience, 13, 134-139.

Morrison, D. F. (1967), Multivariate statistical methods. Mc Graw-Hill, New York, pp.415.

Patil, V. S.; Kedr, V. P. and Nagre, P. K. (1989), Effect of foliar sprays of plant growth regulators and urea on premature and preharvest fruit drop in 'Kinnow' mandarin. PKV Res. J., 13, 161-163.

Primo, E. et al. (1966), 2,4-D y 2,4,5-T. Rev. Agroquim. Tecnol. Aliment., 6, 360-365.

Ragone, M. L. (1992), Os reguladores de crescimento no cultivo cítrico na Argentina. Paper presented at Seminário Internacional de Citros, Bebedouro, Brazil.

Rosa, G. J. M. (1994), Desenvolvimento de aplicativo para a análise de perfil na experimentação zootécnica. Dissertação (Mestrado), Universidade Estadual Paulista, Botucatu, Brazil.

Saravoski, R. A. and Stannard, M. C. (1974), Controlling preharvest drop of citrus. New South Gazette, 9, 3-5.

Stewart, W. S. and Hield, H. Z. (1950), Effects of 2,4-Dichlorophenoxyacetic acid and 2,4,5Trichlorophenoxyacetic acid on fruit drop, fruit production, and leaf drop of lemon trees. Proc. Am. Soc. Hortic. Sci., 55, 163-171.

Zaragoza, S.; Carreres, R.; De Barreda, D. G.; Alonso, E.; Del Busto, A. and Prado, S. (1977), Recolección tardía de la naranja 'Washington'navel - Delayed harvest of Washington Navel oranges. Paper presented at 2. International Citrus Congress, Orlando, E.U.A. 